\title{
The Florida Right to Farm Act ${ }^{1}$
}

\section{Jana Caracciolo, Raychel Thomas, and Catherine Campbell ${ }^{2}$}

\section{Introduction}

Every state has a right to farm act, but the ways in which these acts affect farming operations differ from state to state. Generally, right to farm acts were put in place to protect agricultural producers from nuisance lawsuits. The purpose of a nuisance lawsuit is to stop someone from doing something that produces a nuisance, such as excessive noise, odor, dust, smoke, light, and increased traffic. There are two main types of nuisance lawsuits. The first are private nuisance claims, which are disputes between individuals or neighbors and are sometimes referred to as "not in my backyard" or "NIMBY" claims. The second type of nuisance claims are public nuisance claims, which are usually brought by local governments for the purpose of eliminating a general harm that negatively impacts public health, safety, or welfare. Right to farm acts were put in place to protect farmers facing private or public nuisance lawsuits. Right to farm acts limit how and when someone can bring a nuisance suit against a farm.

To help protect agriculture from public nuisance claims, some states, including Florida, also provide farms with protection from regulation by local governments. There are two main parts to the Florida Right to Farm Act. The first part offers farms a defense if they are sued for causing a nuisance. The second part is a protection from local regulations. This EDIS publication is for Florida residents, local government elected officials and staff, and farm owners and operators who are interested in knowing more about how Florida’s Right to Farm Act protects against nuisance lawsuits and how it affects local governments' ability to regulate farming operations.

This EDIS publication is designed to provide an accurate and current summary of the Florida Right to Farm Act. (See also Olexa et al., 2017.) However, the reader should be aware that because the laws, administrative rulings, and court decisions are subject to constant revision, portions of this publication could become outdated at any time. This publication is distributed with the understanding that the authors are not engaged in rendering legal or other professional advice, and the information contained herein should not be regarded as a substitute for professional advice. For these reasons, the use of these materials by any person constitutes an agreement to hold harmless the authors, the Institute of Food and Agricultural Sciences, and the University of Florida for any liability claims, damages, or expenses that may be incurred by any person as a result of reference to or reliance on the information contained in this publication. The Florida Right to Farm Act is found in Chapter 823, Section 14 of the Florida Statutes (https:// www.flsenate.gov/Laws/Statutes/2014/0823.14).

1. This document is FCS3357, one of a series of the Department of Family, Youth and Community Sciences, UF/IFAS Extension. Original publication date July 2021. Visit the EDIS website at https://edis.ifas.ufl.edu for the currently supported version of this publication.

2. Jana Caracciolo, J.D., former student associate, Conservation Clinic, University of Florida Levin College of Law; Raychel Thomas, J.D., former student associate, Conservation Clinic, University of Florida Levin College of Law; and Catherine Campbell, Ph.D., M.P.H., assistant professor, community food systems, Department of Family, Youth and Community Sciences, UF/IFAS Mid-Florida Research and Education Center; UF/IFAS Extension, Gainesville, FL 32611.

The Institute of Food and Agricultural Sciences (IFAS) is an Equal Opportunity Institution authorized to provide research, educational information and other services

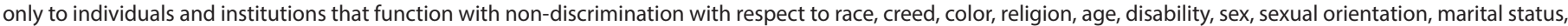

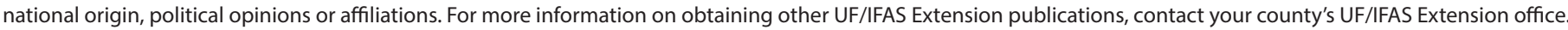
U.S. Department of Agriculture, UF/IFAS Extension Service, University of Florida, IFAS, Florida A \& M University Cooperative Extension Program, and Boards of County Commissioners Cooperating. Nick T. Place, dean for UF/IFAS Extension. 


\section{Part 1 of the Florida Right to Farm Act: Protection from Nuisance Lawsuits}

The first part of the Florida Right to Farm Act regulates how and when a person can bring a private nuisance claim against a neighboring farm. The Florida Right to Farm Act gives farms that are facing a nuisance lawsuit a defense. In other words, when someone sues a neighboring farm, the farm can use the right to farm defense. To succeed when bringing a right to farm defense, the farm must meet a few criteria. The text of the Florida Right to Farm Act says that the defense is available to "farm operations," defined as "all conditions or activities by the owner, lessee, agent, independent contractor, and supplier which occur on a farm in connection with the production of farm, honeybee, or apiculture products and includes, but is not limited to, the marketing of produce at roadside stands or farm markets; the operation of machinery and irrigation pumps; the generation of noise, odors, dust, and fumes; ground or aerial seeding and spraying; the placement and operation of an apiary; the application of chemical fertilizers, conditioners, insecticides, pesticides, and herbicides; and the employment and use of labor" (Florida Statute 823.14(3)(c)).

This means that the right to farm defense is available to more farms than just the "bona fide agricultural operations" defined in the Greenbelt Law (Thomas et al., 2021). According to the Florida Greenbelt Law, a "bona fide farm operation" is a farm operation that is engaged in good faith commercial agricultural use of land on land that has been classified as agricultural (Florida Statute 193.461(3)(b)). Table 1 lists key terminology and definitions.

Although the definition of "farm operation" is broad, the Florida Right to Farm Act does include some limitations. In order for a farm operation to be eligible to use the right to farm defense when sued by a neighbor, the farm must have been in operation for more than one year at the time of the lawsuit. This functions like a statute of limitation. The suing neighbor loses their ability to sue for nuisances caused by the farm if they failed to sue within the farm's first year of operating. Next, in order for a farm to use the right to farm defense, the farm must not have been a nuisance when the farm began its operation, and the farm must comply with "generally accepted agriculture and management practices" (Florida Statute 823.14(4)(a)). Note that the act says generally accepted agricultural and management practices, rather than specifying the Florida Department of Agriculture and Consumer Services (FDACS) Best Management Practices (BMPs), which have specific rules and manuals to guide agricultural practices to conserve water and protect water quality (FDACS, n.d.).

Farms sometimes change their type of operation or farm ownership. The Florida Right to Farm Act specifically states that a farm can still use the right to farm defense even if the farm has recently experienced a change in farm ownership, type of farm product, or its practices to stay in compliance with best management practices. For example, because of citrus greening, a citrus farm may have shifted their operations to blueberries. If a neighbor who owns property near the farm that is now a blueberry farm sues the farm based on the claim that the smell of the mulch used in the blueberry production is a nuisance, the now-blueberry farmer can still use the right to farm defense, even though the operation shifted within the last year. In other words, the farm's establishment date is the time the citrus farm was established, not when the blueberries were planted.

The Florida Right to Farm Act also specifies that a farm operation is not always insulated from a nuisance lawsuit after a change in farm operations. The act does not "permit an existing farm operation to change to a more excessive farm operation with regard to noise, odor, dust, or fumes where the existing farm operation is adjacent to an established homestead or business" (Florida Statute 823.14(5)).

This limits the use of the right to farm defense in cases when a nuisance claim arises from a farm operation located near homes or businesses that produces increased amounts of noise, odor, dust, or fumes.

Finally, the Florida Right to Farm Act identifies specific conditions that, if they are present on a farm and are the cause of the nuisance lawsuit, will remove the farmer's ability to use the right to farm defense. In cases when a farm operation has or does these things-regardless of the time the farm has been in operation or any other factors that normally are relevant to whether the farm can use the Florida Right to Farm Act as a defense-the farm is not protected under the Florida Right to Farm Act from nuisance lawsuits. These conditions are:

1. The presence of untreated or improperly treated human waste, garbage, [animal waste], dead animals, dangerous waste materials, or gases which are harmful to human or animal life.

2. The presence of improperly built or improperly maintained septic tanks, water closets, or privies. 
3. The keeping of diseased animals which are dangerous to human health, unless such animals are kept in accordance with a current state or federal disease control program.

4. The presence of unsanitary places where animals are slaughtered, which may give rise to diseases which are harmful to human or animal life (Florida Statute 823.14(4)(a)).

\section{Part 2 of the Right to Farm Act: Protection from Local Regulations}

In addition to insulating farms from nuisance lawsuits, the Florida Right to Farm Act also provides farms with protection from local regulations. As a basic legal principle, a state or local government can utilize what are referred to as its "policy powers" to regulate an activity to promote public health, safety, and welfare. Regulating agriculture often falls into this category. To protect agriculture from local regulations, the Florida Right to Farm Act limits local governments' ability to regulate agriculture.

The Florida Right to Farm Act prohibits a local government from adopting any ordinance, regulation, rule, or policy that prohibits, restricts, regulates, or otherwise limits "an activity of a bona fide farm operation on land classified as agriculture [according to Florida's Greenbelt Law, when that] activity is regulated through implemented best management practices or interim measures developed by the Department of Environmental Protection, the Department of Agriculture and Consumer Services, or water management districts and adopted ... as part of a statewide or regional program.”

Essentially, this means that if the state of Florida already regulates a farm activity, then local governments cannot apply additional regulations, rules, limitations, etc., on that activity. Note that there are two parts to the limitation quoted above. The farm must be a bona fide farm operation on land classified as agricultural according to the Florida Greenbelt Law, and it has to be regulated via FDACS BMPs or interim measures. A local government cannot pass local regulations on farm activities if both of these conditions are met-if either of the two parts is missing, then the local government is free to regulate.

The first part is that the activity must be done by a bona fide farm operation classified as agricultural under the Florida Greenbelt Law (Thomas et al., 2021). This part of the Florida Right to Farm Act is written in a way that is unclear. It is unclear whether local governments are preempted from regulating any farm operation that could receive the greenbelt classification (even if the farm has not applied for and received that classification), or whether local governments are prohibited from regulating only those farms that have applied for and actually received the greenbelt tax classification. Unfortunately, this question is currently unanswerable. The only way this question will be answered is if the state legislature amends the act to state more clearly what it means or if a lawsuit is initiated that specifically requires a judgment on this question. In the case of a lawsuit, the question will ultimately be answered by the verdict of a judge who will take into consideration the text of the statute, the policy implications, and the intent of the legislature.

The second condition that must be met to prevent local regulation is that the activity the local government wishes to regulate must be an activity already regulated by the state through best management practices (BMPs) or interim measures. FDACS BMPs are defined in the 2020 Environmental Resource Management Bill (House Bill 1091/Senate Bill 712, https://www.flsenate.gov/Session/ Bill/2020/712). There are currently ten BMP manuals in the state of Florida that describe best management practices for different agricultural systems. For more information, see FDACS (n.d.). These manuals are considered implemented BMPs and are created through a formal process. When the Florida Right to Farm Act mentions interim measures, it is referring to temporary regulations that the government may not have fully implemented yet. Therefore, because of the Florida Right to Farm Act, a local government may not create additional regulations on top of those found in the FDACS BMP manuals or in any interim measure. As time goes on, there may be more state regulations that apply to farming operations; thus, there may be fewer agricultural activities that local governments can regulate.

Putting the two elements of the Florida Right to Farm prevention of local regulation language together, a local government is free to regulate agriculture if the activities are conducted by a farm operation that is not bona fide or if the state does not yet regulate the activity.

\section{Conclusion}

The Florida Right to Farm Act has important implications and protections for Florida's farmers. It provides farm operations with protection from lawsuits that claim that a farm operation is a nuisance either to an individual or to the public. This protection only applies after a farm has been in operation for a year, if it operates in accordance with generally accepted agricultural practices, and if it was not a nuisance when it began operation. This protection 
applies even if the farm changes ownership or farming activities, provided that change does not increase the intensity of the operation if it is adjacent to homes or businesses. This means that a farm can be subject to a nuisance suit from either an individual or a local government within the first year of operation.

Local governments, such as cities or counties, cannot regulate activities of bona fide commercial farm operations if those activities are already regulated by the state via BMPs or interim measures developed by FDACS, the Department of Environmental Protection's Office of Agricultural Water Policy, and DEP water management districts (https://floridadep.gov/water-policy/water-policy/ content/water-management-districts). In cases when the activities are not already regulated by the state or when the activities are not being conducted by a bona fide farm, then a local government is free to pass local rules, regulations, or limitations.

Understanding these two parts of the Florida Right to Farm Act-the protection from nuisance suits and the prevention of local regulation-is important for farm operators, local governments, and Florida residents. The act provides guidance for when a resident or local government can and cannot sue a farm, and it specifies what types of activities a local government can regulate. This information is important for farm operations, community residents living next to a farm operation, and local governments.

\section{References}

Florida Department of Agriculture and Consumer Services. (n.d.). Agricultural Best Management Practices. Accessed on July 6, 2021. https:// www.fdacs.gov/Agriculture-Industry/Water/ Agricultural-Best-Management-Practices

Florida Greenbelt Law. Florida Statute 193.461. https:// www.flsenate.gov/Laws/Statutes/2014/193.461

Florida Right to Farm Act. Florida Statute 823.14. https:// www.flsenate.gov/Laws/Statutes/2014/0823.14

Olexa, M. T., Borisova, T., \& Davis, J. (2021). 2021 Handbook of Florida Water Regulation: Florida Right-to-Farm Act. FE599. Gainesville: University of Florida Institute of Food and Agricultural Sciences. https://edis.ifas.ufl.edu/ fe599
Thomas, R., Caracciolo, J., \& Campbell, C. (2021). How to Apply for Greenbelt Agricultural Tax Assessment. FCS3358. Gainesville: University of Florida Institute of Food and Agricultural Sciences. https://edis.ifas.ufl.edu/fy1497 
Table 1. Key terminology.

\begin{tabular}{|c|c|}
\hline Laws & \\
\hline Florida Right to Farm Act & $\begin{array}{l}\text { Florida Statute } 823.14 \\
\text { Protects farm operations, meeting specific criteria, from nuisance lawsuits. } \\
\text { Limits local regulation of "bona fide farm operations on land classified as agricultural" according to the } \\
\text { Florida Greenbelt Law, if that operation is subject to state regulation, such as FDACS BMPs. } \\
\text { https://www.flsenate.gov/Laws/Statutes/2014/0823.14 }\end{array}$ \\
\hline Florida Greenbelt Law & $\begin{array}{l}\text { Florida Statute } 193.461 \\
\text { Provides for preferential tax treatment for farms engaged in good faith commercial agriculture. } \\
\text { Specifies the criteria for land to be classified as "agricultural" for tax purposes. } \\
\text { https://www.flsenate.gov/Laws/Statutes/2014/193.461 }\end{array}$ \\
\hline \multicolumn{2}{|l|}{ Definitions } \\
\hline Farm & $\begin{array}{l}\text { "Land, buildings, support facilities, machinery ... used in the production of farm or aquaculture products" } \\
\text { (Florida Statute } 823.14(3)(a)) \text {. }\end{array}$ \\
\hline Farm operation & $\begin{array}{l}\text { "All conditions or activities by the owner, lessee, agent, independent contractor, and supplier which occur } \\
\text { on a farm in connection with the production of farm, honeybee, or apiculture products and includes, but } \\
\text { is not limited to, the marketing of produce at roadside stands or farm markets; the operation of machinery } \\
\text { and irrigation pumps; the generation of noise, odors, dust, and fumes; ground or aerial seeding and } \\
\text { spraying; the placement and operation of an apiary; the application of chemical fertilizers, conditioners, } \\
\text { insecticides, pesticides, and herbicides; and the employment and use of labor" } \\
\text { (Right to Farm Act, Florida Statute } 823.14(3)(b)) \text {. }\end{array}$ \\
\hline Bona fide agricultural purposes & $\begin{array}{l}\text { "Good faith commercial agricultural use of the land" } \\
\text { (Greenbelt Law, Florida Statute } 193.461(3)(b)) .\end{array}$ \\
\hline Agricultural purposes & $\begin{array}{l}\text { "Includes, but is not limited to, horticulture; floriculture; viticulture; forestry; dairy; livestock; poultry; bee; } \\
\text { pisciculture, if the land is used principally for the production of tropical fish; aquaculture...; algaculture; sod } \\
\text { farming; and all forms of farm products as defined in [Florida's Right to Farm Act] and farm production" } \\
\text { (Greenbelt Law, Florida Statute } 193.461 \text { (5)). }\end{array}$ \\
\hline
\end{tabular}

